\title{
How to rediscover the ubuntu paradigm in education
}

\author{
joan.Osa Oviawe ${ }^{1,2}$
}

Published online: 13 February 2016

(c) Springer Science+Business Media Dordrecht and UNESCO Institute for Lifelong Learning 2016

I am. Because we are. Ubuntu

This special issue emerged from the 59th annual conference of the Comparative and International Education Society (CIES) held in Washington D.C. on 8-13 March 2015. The theme of the conference was "Ubuntu! Imagining a Humanist Education Globally". The decision to produce this issue and the process for the selection of topics originated from a convergence of interests among the CIES conference organisers, the editorial team of the International Review of Education (IRE) and one IRE Consulting Editor. Subsequently, we - the former CIES President-Elect (now President), the former Conference Chair and the IRE Consulting Editor agreed to serve as Guest Editors of this special issue.

All three Guest Editors took part in the CIES "presidential panel” entitled "Recentering Education as a Moral Enterprise". We subsequently decided to invite the participants of the panel to contribute to this special issue. There was an insightful engagement among the panellists, as well as constructive contributions from the audience that attended the session. Participants articulated various perspectives and raised pertinent questions. One of these questions concerned the notion of "recentring" which, critics argued, assumes education had been centred before, whereas in fact it had never been. However, while the arguments enriched the debates, some of the points made led to the realisation of a need to provide further clarification about the connotation of "re-centring".

The idea of "re-centring" neither assumes a universal moral foundation of education nor does it intend to present indigenous education in romantic terms. As argued by Boubou Hama (1968), there is a need for critical assessment while reaffirming the substance of integrative philosophy and collective ethos. Thus, the

$₫$ joan.Osa Oviawe

joo26@cornell.edu

1 Cornell University, Ithaca, NY, USA

2 Grace Foundation for Education and Development, Benin City, Edo State, Nigeria 
initial panel title was in reference to the indigenous education of societies that were colonised and were forced to abandon and devalue their more inclusive forms of education. It was not conceptualised to apply to colonial education in general that was in essence an instrument of domination and control, irrespective of the practical methods used by the different colonial powers to set up and organise their respective systems. Policies and practices that are now entrenched in contemporary education systems of former European colonies contradict officially declared policies and pronouncements on education, even at the basic level, as free and compulsory. Indeed, in most cases this education is de facto exclusionist of youth, rural dwellers and marginalised urban populations.

Following a fruitful exchange of perspectives, the initial panel title was revised to produce the present title of this special issue. The initial choice of the panel topic was to provide a forum for a critique of the European/colonial education systems that were set up in colonised societies of the Global South, including Africa. This education was conceptualised, designed and implemented as an instrument of a colonial rule founded on unequal rights and marginalisation of the colonised, for whom education was not considered a right by the colonial system. Thus, few of the school-age youth from colonised societies were enrolled. Furthermore, those who were enrolled had access only to basic education. By and large, with only limited exceptions, before independence, higher education was not made available to the native populations. Rather, typically they were technically trained to serve the colonial system. In Universities: British, Indian, African: A study in the ecology of higher education, Eric Ashby (1966) eloquently articulated dimensions of the process of the transfer of higher education from the colonial power to the colonies.

Recently, IRE published a special issue in English and French entitled "What humanism for the 21st century? Quel humanisme pour le 21e siècle?" (Halimi 2014). This is an indication of the aforementioned convergence of interests that led to this special issue, made up of a total of four articles and two research notes addressing the issue of "Rediscovering the Ubuntu Paradigm in Education" from different regional and thematic perspectives. I am grateful to my Co-Guest Editors N'Dri Assié-Lumumba and Birgit Brock-Utne - for the experience of working together on this special issue as well as for their valuable feedback and contributions to this introduction. I also acknowledge Stephen Roche, Executive Editor of IRE who provided the opportunity for us to work on this special issue.

\section{The ubuntu paradigm}

This introduction contends that there is a need to include alternative paradigms in education that are less positivistic, Eurocentric and individualistic than what has become the norm today. It does not argue for a wholesale elimination of the more hegemonic Eurocentric paradigm that is predominant in various education systems. Rather, a combination of valuable attributes of the positivistic and the non-linear organic systems of knowledge might create the ideal framework to foster an ethos of a holistic, transformative and emancipatory educational experience for all. In a nutshell, there is a place for an ubuntu philosophy in education both in Africa and 
around the world. In the quest to rediscover the ubuntu paradigm in education, our intention is to advance its humanistic ethos and paradigmatic alternative that can fully complement, with its emphasis on human connections and interdependency, the Western positivistic, linear and mechanistic paradigms.

Ubuntu is envisioned as a framework that is part of the humanist traditions of broader African belief systems, although this specific term originates in Southern Africa. Ubuntu is a philosophy of being that locates identity and meaning-making within a collective approach as opposed to an individualistic one. As a result, the individual is not independent of the collective; rather, the relationship between a person and her/his community is reciprocal, interdependent and mutually beneficial. Other indigenous belief systems such as Confucianism offer a similar perspective. Like ubuntu, Confucianism espouses a view of education that is closely intertwined with a moral imperative, which serves as the foundation for an education imbued with morality. According to Jun Li (2015), in Confucianism, the "Five Constant Virtues of a gentleperson, i.e., Ren (Benevolence), Yi (Righteousness), Li (Propriety), Zhi (Wisdom) and Xin (Sincerity), are all key moral elements that should be cultivated through a humanistic education."

According to Jerry Willis, "[a] paradigm is thus a comprehensive belief system, world view, or framework that guides research and practice in a field" (Willis 2007, p. 8). As a paradigm, ubuntu helps to deal with the nature of being (i.e., ontology) regardless of whether this knowledge is intrinsic or extrinsic, and provides a framework to distinguish belief from opinion (i.e., epistemology). It also involves the theoretical and systematic analysis of a set of procedures through which a particular belief system is practised (i.e., methodology). In education, several Western and non-Western paradigms are utilised in the school environment. Consequently, each paradigm influences different theories of teaching and learning, pedagogy, curriculum, assessment, professional development, language of instruction, and so on.

Although similar, indigenous paradigms and belief systems are culturally grounded and developed to fit the specific needs of their respective societies without being closed to others' needs as long as these are not imposed. Hence, imagining a global humanist education means utilising a framework that may be more local and at the same time open to the global, while being complementary of and consistent with the indigenous and the colonial systems of education (Assié-Lumumba 2004). In Africa, rediscovering the ubuntu paradigm in education is a first step towards reclaiming the African educational space in order to create education systems that are culturally and intellectually relevant (Oviawe 2013). A pedagogical and curricular ethos that is underpinned by the philosophical foundations of ubuntu would help to ameliorate the long-standing effects of the colonial legacy of the received education system in Africa; in effect it will "erase the lingering colonial smile" (quoted in Oviawe 2013) and counter what Harry Lewis (2007) refers to as "excellence without a soul".

N'Dri Thérèse Assié-Lumumba, in this issue's opening article entitled "Evolving African attitudes to European education: Resistance, pervert effects of the singlesystem paradox, and the ubuntu framework for renewal" provides a critical examination of the pre-colonial and post-independence struggles by Africans to 
achieve emancipation from the dominance of neo-colonial and neo-liberal ideologies in the shaping of African education. These have tended to skew education away from what the locals need to the privileged Western and Eurocentric paradigms. Adopting the methodological approach of historical structuralism which, in the author's words, "stipulates that social reality and facts are determined and created by social agents within structural and historical contingencies", she uses historical and contemporary analysis of the evolving attitudes towards European education. This approach allows for an in-depth interrogation of the numerous ineffectual efforts at educational reform in Africa. Citing Cheikh Anta Diop, who contends that African "[i]ntellectuals should study the past not for their pleasure but to learn useful lessons", Assié-Lumumba goes beyond the basic social, economic and cultural needs of Africans to analyse the historical and contemporaneous issues reaffirming the colonial legacy of education in Africa as it impacts on the present, while looking to draw on the indigenous past to create a plan for the future. Consequently, she argues that "[a] critical assessment of their history is necessary for Africans if they are to produce and use knowledge in all its forms, at the local and global levels, to build the foundation for self-sustaining social progress".

Citing Joseph Ki-Zerbo (1990) to buttress her argument that education is a precondition for Africa's progress, Assié-Lumumba (2000) also argues elsewhere that the systems of education that have been designed for Africa with external influence have been a liability rather than an impetus for advancement. In his call to provide education as a universal sine qua non for survival and social progress, Ki-Zerbo expresses the need to recognise and organise a human-centred education that acknowledges the critical importance and centrality of the community. In his critical examination of the colonial legacy of education and reflections on the net outcome of post-colonial international cooperation with Africa, he writes: "The larger truth, though, is that in practically all cases, interactions between Africa and the outside world have turned out to Africa's disadvantage", thus "leaving a negative balance when all costs in such sectors as agriculture, food, trade, tourism, technology, health, communication, etc. are taken into account." Therefore, "[o]f all these interfaces shaping tomorrow's Africa, it is the educational sector, informal as well as formal, that presents the most absurdly negative aspect" (Ki-Zerbo 1990, pp. 11-12).

Arguing for a true instrument that promotes social progress, Assié-Lumumba contends that education must be systematically conceptualised, designed and organised as a comprehensive system in which all levels, types and dimensions of education - from pre-school to higher education - must be functionally integrated and equally valued. In this system of education, learners cannot be characterised as "waste" as is the case in the received system, when it has failed them. Attrition, whether in the form of dismissal or "voluntary" dropout, cannot constitute any part of education for social progress as it ejects individuals and groups, especially the female population, that ought to be included in any development agenda (AssiéLumumba 2005). As Ali Mazrui argues, there is, in addition to or as a corollary of colonial education, a "new international cultural order" characterised by structural inequality in which Africa is located at the margin of the global world and depends on the former colonial powers that remain the centres of decisions that consistently 
apply conditions of disadvantage to education in Africa in general, and African higher education in particular (Mazrui 1992, p. 96).

As indicated earlier, although the term "ubuntu" stems from a Southern African language, as a concept for articulating solidarity and togetherness it has parallels across the African continent and other regions of the world. Its meaning of collective ethos has been popularised by various authors including the novelist, scholar and journalist Jordan Kush Ngubane in the 1950s and more recently by public figures such as Nelson Mandela and Desmond Tutu articulating inclusiveness and equality.

There is a need to rediscover alternative paradigms like ubuntu that shift the dominant Western-Eurocentric gaze from an over-reliance on positivism, Eurocentrism, classism and individualism to a more human-centred and holistic approach that recognises the interdependences within the ecosystem of people, planet and place. The universe is a network of interdependent systems embedded within micro systems, just as the human body comprises a multiplicity of organs, each connected to a group of cells, molecules and atoms. Communities are networks of relationships both biological and social that exist within a given ecosystem. It is clear that humans and nature are intertwined and have a relationship of reciprocity whereby one depends on the other to survive. Indeed, the collective ethos is not limited to human communities only but rather they are connected to their environment. Systems theory provides a model that helps to explain how nature works and how the parts make up the whole. This view encompasses both finite and infinite relationships of dependency and intertwined communities. Like ubuntu, systems thinking provides a roadmap for viewing the world in a more holistic and ecologically sound manner, revealing the processes behind the connections and patterns that crystallise seemingly separate parts into a unified whole.

Just as there is a predominance of positivistic thinking in the Western world, systems thinking has historically formed the fulcrum of thought and ways of doing in other cultures, such as Eastern systems of thought like Zen or Taoism. Conversely, many Western societies have moved away from the holistic systems thinking that connects human to nature towards a more positivist and segmented worldview that essentially separates humans from nature. This can be referred to as a dualistic way of thought, which categorises everything into binaries. The global capitalist system which has influenced how education is conceptualised, designed and delivered around the world is often linear and mechanistic as opposed to organic and circular. As a result, communities, institutions and schools reflect silos that are reinforced with different levels of specialisation and credentialling.

The prevailing neo-liberal ideology that forms the framework of modern education reinforces the Marxist critique that education propagates the oppressive nature of capitalism by maintaining an unequal class structure that tends to privilege the ruling class (bourgeoisie) over the working class (proletariat). Hence, the dominant characteristics of the modern school are tailored to address the needs of the ruling class. This has shaped standardised testing, commercialisation, globalisation of schools, competitiveness and managerialism. Beginning with the industrial revolution in the 18th century and continuing to the hypermodern and technological age of the present, capitalist values have become embedded in 
education such that the humanistic values of education have been replaced by market-driven, mechanistic and commercialist benchmarks for measuring educational success. As a result, education is seen as an investment that must yield economic returns. This means that greater emphasis is placed on credentialism and the global ranking systems which pit country against country, and standardised assessment tests like the Programme for International Student Assessment (PISA) become the yardstick for measuring students' cognitive development.

This critique of the neo-liberal ideology that is permeating education, particularly in the Global South, is reflected in Birgit Brock-Utne's article entitled "The ubuntu paradigm in curriculum work, language of instruction and assessment". This article discusses the ubuntu paradigm as a framework for reforming language of instruction, curriculum and assessment in sub-Saharan Africa. She argues that the "basic African worldview is fundamentally different from the European or Arabic, however much Christianity or Islam may have proselytised in Africa". Thus, "[o]pening up curriculum content to African culture as expressed through African languages, sciences, arts, crafts and religious beliefs involves reconceptualising content from an African perspective. In the African tradition knowledge is experientially and socially based rather than propositionally derived."

The ideology that frames education also creates the culture of schools; thus, the school is organised in silos - from courses of study to grading to sorting children and assigning them to different grade levels based on cognitive abilities. Scant attention is paid to how the different subjects are related. This in turns affects how students view themselves in relation to others, which does not accommodate ubuntu human-ness. This practice also extends to the curriculum in terms of which knowledge is privileged (Western) and which is discarded (indigenous). These increasingly reductionist lenses separate any given phenomena into binaries of "good and bad", or "us and them". The dualism enshrined in the education system has influenced the types of epistemologies that are validated, the explicit curriculum (what is taught), hidden curriculum (what is the norm), the null curriculum (what is not taught), language of instruction and assessment practice (Brock-Utne 2009).

In her article, Brock-Utne discusses language policy in Africa at both the microlevel in terms of translanguaging and code-switching, and at the macro-level of prestige planning. She goes on to critically examine, from an ubuntu perspective, the assessment practices taking place in African schools, specifically drawing attention to international tests such as the Trends in International Mathematics and Science Study (TIMMS) and PISA. She argues that countries of the Global South are disadvantaged and less likely to institute educational practices suited to their unique socio-cultural, socio-economic and geo-political realities as long as these continue to be a part of a borrowed system of educational assessment. Brock-Utne argues that the ubuntu philosophy bears similarity to philosophies in Eurasia and Latin America and contrasts with Western ideas such as the Germanic notion of Bildung, which connotes education and formation of the individual through a process of self-development and cultural maturation.

Emphasising the need for an infusion of ubuntu paradigm in African education, Karen Biraimah, in her article entitled "Moving beyond a destructive past to a decolonised and inclusive future: The role of $u b u n t u$-style education in providing 
culturally relevant pedagogy for Namibia", argues for a movement beyond the "destructive" colonial past of Namibia which was characterised by "genocide, brutality and apartheid" under the "successive regimes of Germany and South Africa", to a post-independence era that embraces "greater equality of opportunity and quality of life for all of its citizens", regardless of race, class, ethnicity, gender, disability or mother tongue by providing access to quality education for all. Moving from the colonial legacy of Namibian education will require a cultured and emancipatory pedagogy that is immersed in the paradigm of ubuntu, where "inclusiveness, equity and equality" form its overarching objectives. This more desirable goal comes with its own set of challenges, foremost being high levels of poverty, which has been exacerbated by climate change problems such as drought, the competitive capitalist system of the global economy, and a diverse population with different languages and cultural norms. Biraimah argues that these externalities pose a lot of challenges in the effort to provide equitable access to quality education for all of Namibia's children.

Additionally, the author examines current factors that are both beneficial to Namibia's cultural diversity and also pose a challenge for policy-makers in terms of provision of equitable education for all. In this vein, she contends that inequalities in the education system are reinforced, particularly in terms of the divide between urban and rural and between White Afrikaans-speakers, the Black African majority (comprising different ethnic groups such as the San, Herero, Himba, Nama and Owambo), the Coloured population that migrated from the Cape region of South Africa, and the Basters who trace their mixed ancestry to early white settlers from the Cape and the Khoikhoi indigenous people.

Like Assié-Lumumba and Brock-Utne (this issue), Biraimah argues for an inclusive and culturally relevant pedagogy that is $u b u n t u$-style education. All three papers examine the colonial legacy of African education, the struggle to create an identity for education after more than 50 years of received colonial education postindependence, as well as the important role of language of instruction. The ubuntu paradigm seems to be a way forward to create convergence between the indigenous and the Western, reminiscent of the African philosophy of sankofa, which proposes looking at the past in order to reclaim the future.

The problematics of borrowed education ideology are not confined to Africa. In other parts of the world, but especially in the Global South, there are similarities in terms of issues impacting on the quality of education. The article by Gustavo Fischman and Luis Armando Gandin entitled "The pedagogical and ethical legacy of a 'successful' educational reform: The Citizen School Project" draws parallels between ubuntu and the concept of Escola Cidada, or Citizen School Project in Brazil. This article examines the Citizen School Project and the evaluative process of assessing its strengths and contradictions. The paper takes us through the education reforms in Brazil in the 1980s and 1990s as well as the emphasis on participation and democratisation. The three main goals of the Citizen School Project are stated as democratisation of access to schools, democratisation of schools' administration, and democratisation of access to knowledge. The authors argue that the Citizen School Project has both improved the quality of education in 
Porto Alegre and is an important contribution to collective thinking about the politics of "successful" educational policies.

While drawing on lessons learned from Finland's relative successes in education reform in the 1970s and 1980s, the authors contend that reform strategies applied in Finland then and Brazil now (through the Citizen School Project) show that "there is no perfect educational model, ready to be replicated everywhere". Thus, "[i]f a 'successful' project is to be tried out elsewhere, what should be done is not a replication, but a re-invention based on a translation". Consequently, the adaptation of the original reform idea is "always a rewrite of the original, sensitive to the conditions, the actors and the meaning-making processes of the new site." Fischman and Gandin provide a rich description and analysis of the transformation created and produced by the Citizen School Project, which represents what they refer to as an "equitable and ethical way of conceiving schooling."

Thomas Luschei's research note, entitled "Translating ubuntu to Spanish: Convivencia as a framework for re-centring education as a moral enterprise", analyses the concept of "convivencia", translated as "peaceful coexistence". This is presented as a method of situating education and society in Colombia, particularly the rural school model of Escuela Nueva (New School), which follows a studentcentred approach that is flexible and teaches students how to dialogue, collaborate and self-govern. The author argues that teachers are key actors in the establishment and support of convivencia in schools by teaching and encouraging cooperation among students, in addition to acting as models of convivencia through their own behaviour. Luschei contends that in order for students to practise the ethos of convivencia in the classroom and community, they need to be given "voice and autonomy." This is necessary because, as the author states, "[c]hildren who are treated as passive subjects in isolation from each other will be less likely to work collaboratively to solve problems and to develop a sense of active respect for others, solidarity, fair play, and equity" (this issue). Comparing and contrasting ubuntu with convivencia, Luschei posits that the attributes of convivencia - consisting of "active respect for others, solidarity, fair play and equity" - are in strong alignment with how Desmond Tutu envisions a person who practises the ubuntu ethos as being "open and available to others, affirming of others ... not ... threatened that others are able and good" (cited by Luschei). Although ubuntu and convivencia are localised and situated within the unique contexts of their respective societies, they share a common message of collectivism and humanness.

Both the article by Fischman and Gandin and the article by Luschei follow a common thread of indigenous practices that seek to amplify the non-linear, relational and inter-dependent characteristics of non-Western educational approaches to improve pedagogy and make education more transformative in ways that are reminiscent of Paulo Freire's emancipatory pedagogy.

This issue concludes with a research note by Benjamin Piper entitled "International education is a broken field: Can ubuntu education bring solutions?" In this note, Piper argues that international education is a broken field and raises the question of whether solutions can be found in an ubuntu-inspired approach to education. According to the author, the problem includes donors, implementers and academicians who do not do enough to interrogate the Western hegemonic 
structures in which the field of International Education is grounded. Piper states that this Western hegemony "creates a field where the power imbalances between donors and host governments are not interrogated", "where development workers place too much faith in their own knowledge rather than that of local education experts, and where development practitioners rarely appreciate the privilege of working in countries which are not their own."

The author goes on to suggest ways in which the ubuntu paradigm can impact on the field of international education and development. These include the cultivation of humility among operational officers in the field of education, appreciation for the expertise and skills of natives, incentivising reflective practices that embed appreciation for local culture and expertise, thus "supporting structures which help educational development experts to review their metacognitive processes", diversifying the field to include locals, minorities and female educational development practitioners, and providing opportunities for advancement.

Taken together, the four articles and two research notes published in this special issue provide strong empirical and conceptual analyses of the applicability of the ubuntu paradigm from various regional and thematic perspectives. The papers highlight significant trends in education research, including the importance of privileging indigenous and other alternative approaches, epistemologies and philosophies, while de-emphasising the hegemony of the Eurocentric, positivistic, linear and mechanistic knowledge canons that are still prevalent in education.

The research presented in this special issue shows that the ubuntu paradigm has important implications for changing the prevailing market-driven ethos of education into one that is more moralistic, emancipatory, cultured and relevant to the needs and aspirations of the people. In a nutshell, it helps to bridge the divide between the classroom and the community in order to foster a relationship that is reciprocal and symbiotic, and thus reflective of the ubuntu ideal.

\section{References}

Ashby, E. (1966). Universities: British, Indian, African: A study in the ecology of higher education. London: Weidenfeld and Nicolson.

Assié-Lumumba, N. T. (2000). Educational and economic reforms, gender equity, and access to schooling in Africa. International Journal of Comparative Sociology, 41(1), 89-120.

Assié-Lumumba, N. T. (2004). Sustaining home-grown innovations in highereducation in sub-Saharan Africa: A critical reflection. Journal of International Cooperation in Education, 7(1), 71-81.

Assié-Lumumba, N. T. (2005). African higher education: From compulsory juxtaposition to fusion by choice-forging a new philosophy of education for social progress. In Y. Waghid, B. van Wyk, F. Adams, \& I. November (Eds.), African(a) philosophy of education: Reconstructions and deconstructions (pp. 19-53). Matieland: Stellenbosch University.

Brock-Utne, B. (2009). The adoption of the Western paradigm of bilingual teaching: Why does it not fit the African situation? In K. K. Prah \& B. Brock-Utne (Eds.), Multilingualism: An African advantage. A paradigm shift in African language of instruction polices (pp. 18-51). Cape Town: Centre for Advanced Studies of African Society (CASAS).

Halimi, S. (Ed.) (2014). What humanism for the 21st century? Quel humanisme pour le 21e siècle? International Review of Education: Journal of Lifelong Learning, 60(3). Special issue.

Hama, B. (1968). Essai d'analyse de l'éducation africaine. Paris: Présence africaine. 
Ki-Zerbo, J. (1990). Educate or perish: Africa's impasse and prospects. Dakar/Abidjan: UNESCO Regional Office for Education in Africa/UNICEF West and Central Africa Regional Office.

Lewis, H. R. (2007). Excellence without a soul: Does liberal education have a future? New York: Public Affairs/Perseus Books.

Li, J. (2015). When Confucianism meets Ubuntu: Rediscovering justice, morality and practicality for education and development in East Asian humanities. Pre-conference response to the theme of the 59th annual conference of the Comparative and International Educatoin Society (CIES), Washington, DC, 8-13 March 2015. Retrieved 12 January 2016 from http://cies2015.org/ response-li.html.

Mazrui, A. (1992). Towards diagnosing and treating cultural dependency: The case of the African University. International Journal of Educational Development, 12(2), 95-111.

Oviawe, J. (2013). Appropriating colonialism: Complexity and chaos in the making of a Nigeria-centric educational system (Doctoral Dissertation). Retrieved 2 February 2016 from https://research. wsulibs.wsu.edu/xmlui/bitstream/handle/2376/5022/Oviawe_wsu_0251E_10843.pdf?sequence=1.

Willis, J. W. (2007). Foundations of qualitative research: Interpretive and critical approaches. Thousand Oaks, CA: Sage Publications.

\section{The author}

joan.Osa Oviawe is a Visiting Fellow at the Institute for African Development at Cornell University. She was a Visiting Scholar in the Africana Studies and Research Center at Cornell, Ithaca, NY, USA. Dr Oviawe founded the Grace Foundation for Education and Development, a Nigeria-based non-profit organisation working to improve access and quality in the Nigerian public school system. For more information, see www.gracefoundation.global. She is also the founder of the Africa Special Interest Group (ASIG) of the Comparative and International Education Society (CIES). ASIG is a scholarly community that encourages and supports critical inquiries into African educational issues. The network includes academics, practitioners and graduate students from over 15 countries. 